\title{
Record of Carcharocles megalodon in the Eastern Guadalquivir Basin (Upper Miocene, South Spain)
}

\section{Registro de Carcharocles megalodon en el sector oriental de la Cuenca del Guadalquivir (Mioceno superior, Sur de España)}

\author{
M. Reolid, J.M. Molina \\ Departamento de Geología, Universidad de Jaén, Campus Las Lagunillas sn, 23071 Jaén, Spain. \\ Email: mreolid@ujaen.es / jmmolina@ujaen.es
}

\begin{abstract}
Tortonian diatomites of the San Felix Quarry (Porcuna), in the Eastern Guadalquivir Basin, have given isolated marine vertebrate remains that include a large shark tooth (123.96 $\mathrm{mm}$ from apex to the baseline of the root). The large size of the crown height $(92.2 \mathrm{~mm})$, the triangular shape, the broad serrated crown, the convex lingual face and flat labial face, and the robust, thick angled root determine that this specimen corresponds to Carcharocles megalodon. The symmetry with low slant shows it to be an upper anterior tooth. The total length estimated from the tooth crown height is calculated by means of different methods, and comparison is made with Carcharodon carcharias. The final inferred total length of around $11 \mathrm{~m}$ classifies this specimen in the upper size range of the known C. megalodon specimens.

The palaeogeography of the Guadalquivir Basin close to the North Betic Strait, which connected the Atlantic Ocean to the Mediterranean Sea, favoured the interaction of the cold nutrient-rich Atlantic waters with warmer Mediterranean waters. The presence of diatomites indicates potential upwelling currents in this context, as well as high productivity favouring the presence of large vertebrates such as mysticetid whales, pinnipeds and small sharks (Isurus). These large vertebrates recorded in the Eastern Guadalquivir Basin were potential prey of C. megalodon.
\end{abstract}

Keywords: Carcharocles megalodon; fossil tooth; Guadalquivir Basin; Tortonian.

\section{RESUMEN}

Las diatomitas tortonienses de la antigua Cantera de San Félix (Porcuna, Jaén), en el sector oriental de la Cuenca del Guadalquivir, han proporcionado restos aislados de vertebrados marinos entre los que destaca un gran diente de tiburón (123.96 mm desde el ápice hasta la línea basal de la raiz). La altura de la corona (92.2 mm), su forma triangular con bordes aserrados, la presencia de una cara lingual convexa y una labial plana, conjuntamente con la raíz angulosa y robusta, permiten determinar que este diente perteneció a un ejemplar de Carcharocles megalodon. La alta simetría de la pieza, su tamaño y su relación longitud/anchura de la corona permiten afrimar que se trata de un diente superior anterior. La longitud total estimada para este tiburón, es calculada a partir de diferentes métodos basados principalmente en la comparación con el tiburón blanco Carcharodon carcharias. La longitud total inferida finalmente para este ejemplar ronda los $11 \mathrm{~m}$, lo que permite incluir este ejemplar dentro del rango de los ejemplares de $C$. megalodon de gran tamaño.

Recibido el 8 de julio de 2014 / Aceptado el 10 de febrero de 2015 / Publicado online el 22 de julio de 2015

Citation / Cómo citar este artículo: Reolid, M. \& Molina, J.M. (2015). Record of Carcharocles megalodon in the Eastern Guadalquivir Basin (Upper Miocene, South Spain). Estudios Geológicos 71(2): e032. http://dx.doi.org/10.3989/egeol.41828.342.

Copyright: ( 2015 CSIC. This is an open-access article distributed under the terms of the Creative Commons Attribution-Non Commercial (by-nc) Spain 3.0 License. 
La paleogeografía de la Cuenca del Guadalquivir próxima al Estrecho Nordbético que conectaba el Océano Atlántico con el Mar Mediterráneo, favoreció la interacción de aguas atlánticas frías y ricas en nutrientes con las aguas más cálidas del Mediterráneo. La presencia de diatomitas indica la actividad potencial de corrientes de upwelling en este contexto, así como la alta productividad que suele favorecer a grandes cetáceos y pinnípedos. Estos mamíferos marinos, registrados en el sector oriental d la Cuenca del Guadalquivir fueron potenciales presas de pequeños tiburones como Isurus el gran C. megalodon.

Palabras clave: Carcharocles megalodon; diente fósil; Cuenca del Guadalquivir; Tortoniense.

\section{Introduction}

The Carcharocles megalodon is the largest macropredatory shark to have ever lived. However, the fossil record of this predator is restricted to isolated teeth and vertebral centra due the cartilaginous skeleton of most of the sharks. The most complete specimen is an associated column of around 150 vertebral centra from the Miocene of the Antwerp Basin, Belgium (Leriche, 1926). The record of C. megalodon teeth ranges from 17 to $2 \mathrm{Ma}$ (middle Miocene to Pleistocene) (Gottfried et al., 1996; Purdy, 1996; Pimiento et al., 2010).

Based on tooth size, C. megalodon reached a maximum inferred total length around $16 \mathrm{~m}$ (Randall, 1973; Gottfried et al., 1996), more than twice the reported maximum length of the white shark Carcharodon carcharias with $6.4 \mathrm{~m}$ (Bigelow \& Schroeder, 1948; Randall, 1973; Compagno, 1984). The largest tooth of C. megalodon measures $168 \mathrm{~mm}$ (specimen PF 1168, Field Museum of Natural History of Chicago).

Data on C. megalodon from the Iberian Peninsula are relatively scarce, sometimes reported only as news in the daily press, without scientific revision. Descriptions of remains of $C$. megalodon from the Iberian Peninsula are those of Areitio (1877) and Meseguer Pardo (1924) from Messinian diatomites of the Lorca Basin (Southeastern Spain); Balbino (1995) from uppermost Miocene of the Alvalade Basin (Portugal); and García et al. (2009) from the Arenas Fm (Huelva, Spain) in the western Guadalquivir Basin.

In this work a complete tooth of $C$. megalodon from the Eastern Guadalquivir Basin (South Spain) is reported and examined in detail, including comparisons with other shark teeth of C. megalodon and C. carcharias described in the literature.

\section{Geological setting}

The Guadalquivir Basin is the foreland basin of the Betic Cordillera and it opens directly to the Atlantic to the WSW (Gulf of Cádiz). Autochthonous units to the north and allochthonous units to the south may be differentiated in this basin (Fig. 1A). The allochthonous units are composed by olistostrome deposits and olistoliths, located at the frontal part of the Subbetic nappes, which are mixed with Miocene clays and marls.

The shark tooth was collected in diatomaceous marl blocks obtained from the old quarry of San Félix, located $2 \mathrm{~km}$ south of Porcuna (coord. 37 51'21.4" N; $4^{\circ} 11^{\prime} 21.6^{\prime \prime} \mathrm{W}$ ) (Fig. 1B). The diatomaceous marls are white to yellowish, sometimes laminated, and they alternate locally with greyish marls without visible stratification. These deposits belong to the highest part of the Valenzuela Formation (Aquitanian-Torttonian in age, Tjalsma, 1971), whose stratotype was established in the San Félix Quarry. The marls contain abundant diatoms and subordinately sponge spicules, silicoflagellates and radiolarians. The sediments of the type section (San Felix Quarry area) have a planktic foraminiferal assemblage with Globorotalia menardii, Globigerina globorotaloidea, Globigerina nepenthes and Globigerinoides obliquus, among others (Tjalsma, 1971). This foraminiferal assemblage belong to the zone N16 of planktic foraminifera (Tortonian) equivalent with most of the middle part of the stratotype of the Tortonian. The main diatom assemblages consist mostly of planktic (Thalassionema, Thalassiotrix, Thalassiosira) and scarce benthic (Delphineis) forms typical of cold oceanic upwelling waters (Molina et al., 1987; López-García \& Bustillo, 1994). The outcrops belong to the third and last episode of diatomitic sedimentation defined in this area by Bustillo \& López-García (1997) of the Thalassiosira yabei Zone (Middle Tortonian).

In this area of the North Betic Strait, which connected the Atlantic Ocean to the palaeo-Mediterranean sea, high concentrations of diatomaceous deposits were produced because it was more oceanographically dynamic than the Atlantic. The Guadalquivir Basin was an Atlantic basin connecting with the palaeoMediterranean through small basins (e.g. Granada Basin and Guadix Basin) to the south by straits. 


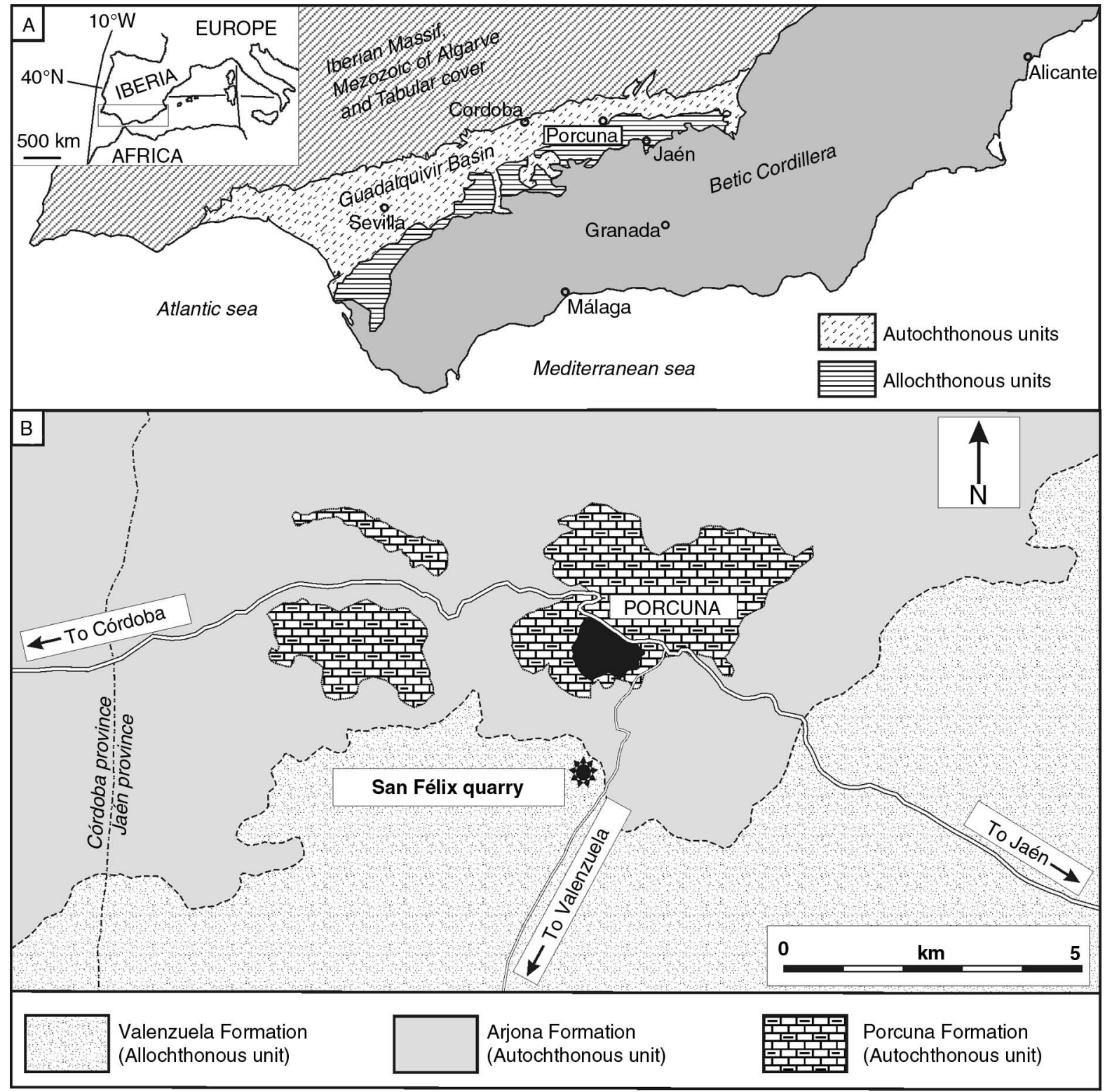

Fig. 1.-Geological setting. A. Location of the Guadalquivir Basin with the autochthonous and allochthonous units. B. Geological sketch of the Porcuna area with the location of the San Félix Quarry.

Flood-tidal currents as well as temperature and salinity gradients favoured movement of sea-water (e.g. Reolid et al., 2012; García-García et al., 2014; Martín et al., 2014). The interaction of the cold nutrient-rich Atlantic waters with the gulfs, bays, small basins and bottom topography of the North Betic Strait caused upwelling, and high productivity of biogenic silica (Molina et al., 1987). The narrowing of the strait from the Langhian to the Tortonian could have caused the progressive upwelling deduced from the study of the diatomites.
This narrowing could also explain the evolution of the upwelling from open sea conditions to near shore conditions (Bustillo \& López-García, 1997).

The youngest part of the Valenzuela Fm, in which the area of the San Felix Quarry is included, has to be considered parautochthonous of the syn-olistostromic sequence of the middle-late Tortonian times (Riaza \& Martínez del Olmo, 1996), while the older parts of the Valenzuela Fm belong no doubt to the allochthonous basin filling that have travelled longer distances. 


\section{Methods}

The tooth analysed, coming from diatomites of the Eastern Guadalquivir Basin, is now displayed in the Museo Obulco (Porcuna, Jaén province). This tooth is described following traditional measurements used by previous authors working on $C$. megalodon and C. carcharias (e.g. Applegate \& Espinosa-Arrubarrena, 1996; Hubbell, 1996; Mollet et al., 1996).

The main measurements for describing the tooth and estimating the total length of the shark are the crown height and the crown width (Fig. 2). According to Gottfried et al. (1996) and Hubbell (1996), the crown height or tooth height is the vertical distance between a straight line touching the lower extensions of the enamel adjacent to the root at the base of the crown and a parallel line touching the tip of the enamel. For these authors, the crown width is the widest part of the enamel at the base of the crown (Fig. 2).
The Recent white shark Carcharodon carcharias is the closest living relative of C. megalodon, and therefore several authors have used skeletal material of $C$. carcharias as the primary basis for comparison with C. megalodon and to infer lifestyle (Uyeno et al., 1989; Applegate, 1991; Gottfried et al., 1992, 1996; Applegate \& Espinosa-Arrubarrena, 1996; Adnet et al., 2010; Pimiento et al., 2010). In order to better approximate the total length of the specimen of C. megalodon from Porcuna, we considered data on crown height and crown width of upper anterior teeth from 102 specimens of $C$. carcharias (85 specimens) and C. megalodon (17 specimens) available in the literature (Table 1).

\section{Results}

This tooth presents the diagnostic characters of C. megalodon such as large size, triangular shape, fine serration on the cutting edges, a convex lingual

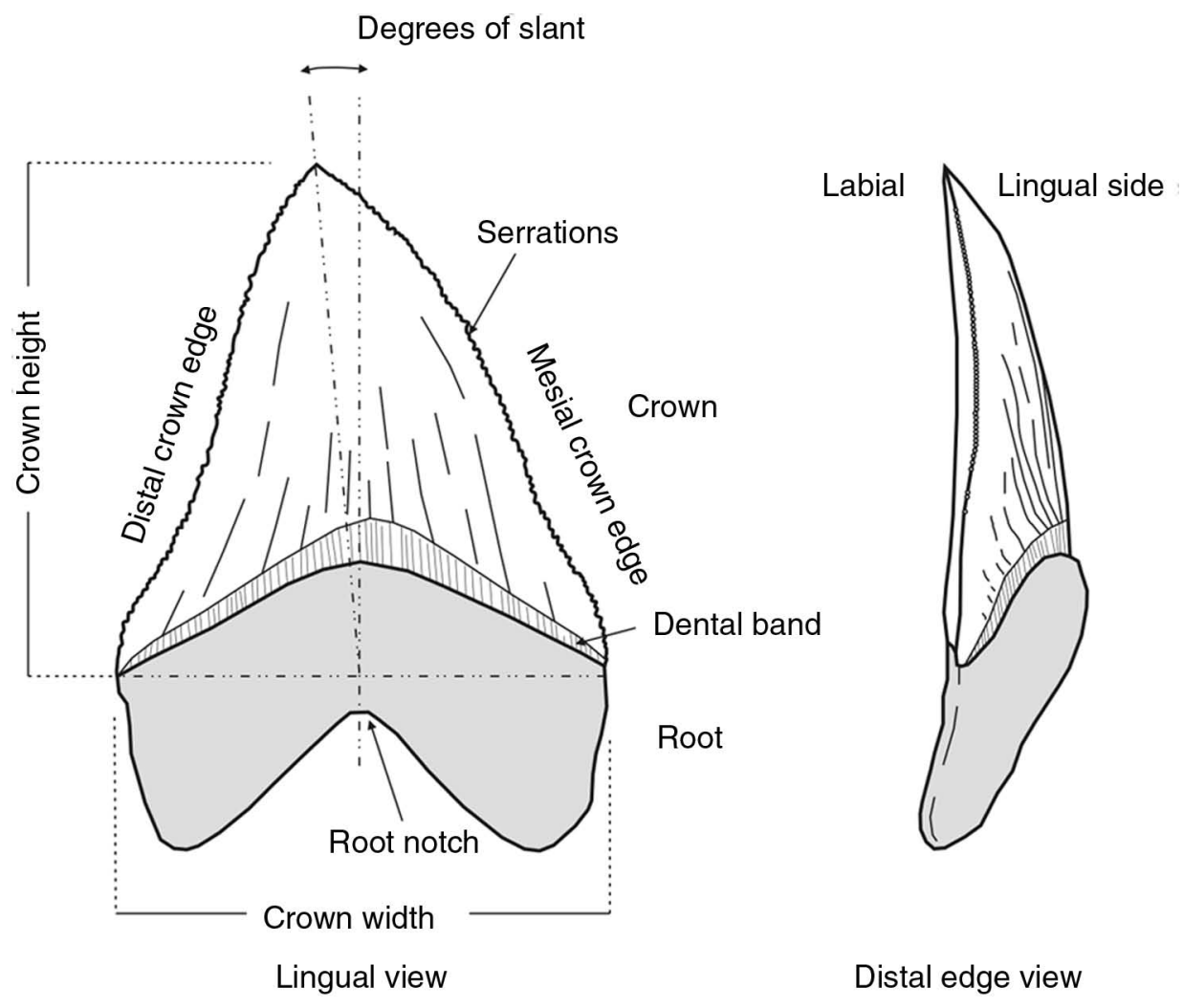

Fig. 2.-Tooth measurements employed in the description of the tooth of Carcharocles megalodon. 
Table 1.-Total length, crown height and crown width from Carcharodon carcharias and Carcharocles megalodon from the upper tooth A2 (locally A3). Note that total length from C. megalodon is calculated according to regression equation proposed by Shimada (2002)

\begin{tabular}{|c|c|c|c|c|c|}
\hline Specimen ID & Total length $(\mathrm{m})$ & Crown height $(\mathrm{mm})$ UA 2 & Crown width (mm) & Genus & Reference \\
\hline & 2.42 & 21.0 & & C. carcharias & Siccardi et al. (1981) \\
\hline & 2.56 & 25.5 & & C. carcharias & Randall (1973) \\
\hline & 2.67 & 24.5 & & C. carcharias & Randall (1973) \\
\hline & 2.71 & 22.5 & & C. carcharias & Randall (1973) \\
\hline & 2.80 & 25.2 & & C. carcharias & Randall (1973) \\
\hline DAE-871111-01 & 2.83 & 23.6 & & C. carcharias & Mollet et al. (1996) \\
\hline DAE-871111-02 & 2.93 & 28.1 & & C. carcharias & Mollet et al. (1996) \\
\hline \multirow[t]{2}{*}{ NSB-BRI-873 } & 3.02 & 28.1 & & C. carcharias & Mollet et al. (1996) \\
\hline & 3.05 & 28.0 & & C. carcharias & Siccardi et al. (1981) \\
\hline UAP 1303 & 3.07 & 27.5 & 21.5 & C. carcharias & Cione et al. (2012) \\
\hline \multirow[t]{3}{*}{ UAP 1301} & 3.10 & 22.7 & 24.5 & C. carcharias & Cione et al. (2012) \\
\hline & 3.14 & 26.0 & & C. carcharias & Randall (1973) \\
\hline & 3.31 & 29.9 & & C. carcharias & Randall (1973) \\
\hline F61583B & 3.35 & 28.5 & 21.0 & C. carcharias & Hubbell (1996) \\
\hline \multirow[t]{3}{*}{ F6785A } & 3.35 & 30.0 & 23.0 & C. carcharias & Hubbell (1996) \\
\hline & 3.64 & 38.0 & 36.0 & C. carcharias & Mollet et al. (1996) \\
\hline & 3.71 & 31.0 & & C. carcharias & Randall (1973) \\
\hline \multirow[t]{2}{*}{ T4239 } & 3.79 & 32.5 & 25.0 & C. carcharias & Hubbell (1996) \\
\hline & 3.79 & 32.5 & 26.0 & C. carcharias & Mollet et al. (1996) \\
\hline SP22294 & 3.91 & 32.5 & 28.0 & C. carcharias & Hubbell (1996) \\
\hline F6785B & 3.96 & 33.0 & 25.0 & C. carcharias & Hubbell (1996) \\
\hline F83083 & 3.96 & 33.0 & 30.0 & C. carcharias & Hubbell (1996) \\
\hline \multirow[t]{2}{*}{ F2680B } & 3.96 & 35.5 & 31.0 & C. carcharias & Hubbell (1996) \\
\hline & 4.08 & 35.5 & & C. carcharias & Randall (1973) \\
\hline F12484B & 4.11 & 33.5 & 25.0 & C. carcharias & Hubbell (1996) \\
\hline H31683 & 4.11 & 34.0 & 28.0 & C. carcharias & Hubbell (1996) \\
\hline H93086 & 4.17 & 38.5 & 35.0 & C. carcharias & Hubbell (1996) \\
\hline F81287 & 4.27 & 35.0 & 27.0 & C. carcharias & Hubbell (1996) \\
\hline F9886A & 4.27 & 34.0 & 28.0 & C. carcharias & Hubbell (1996) \\
\hline F4683 & 4.27 & 33.0 & 30.0 & C. carcharias & Hubbell (1996) \\
\hline $\mathrm{X} 11384 \mathrm{C}$ & 4.27 & 34.5 & 30.0 & C. carcharias & Hubbell (1996) \\
\hline ADCJ & 4.27 & 36.0 & 50.1 & C. carcharias & Hubbell (1996) \\
\hline F122793 & 4.27 & 35.0 & & C. carcharias & Hubbell (1996) \\
\hline H32089 & 4.42 & 40.5 & 33.0 & C. carcharias & Hubbell (1996) \\
\hline F51089 & 4.57 & 35.0 & 28.0 & C. carcharias & Hubbell (1996) \\
\hline H72689 & 4.57 & 37.0 & 34.0 & C. carcharias & Hubbell (1996) \\
\hline \multirow[t]{3}{*}{ F9682 } & 4.57 & 42.0 & 34.0 & C. carcharias & Hubbell (1996) \\
\hline & 4.67 & 34.0 & & C. carcharias & Royce (1963) \\
\hline & 4.70 & 37.0 & & C. carcharias & Mollet et al. (1996) \\
\hline SW41285 & 4.71 & 39.5 & 39.0 & C. carcharias & Hubbell (1996) \\
\hline S41285 & 4.71 & 40.0 & & C. carcharias & Mollet et al. (1996) \\
\hline G121382 & 4.72 & 38.5 & 33.0 & C. carcharias & Hubbell (1996) \\
\hline \multirow[t]{2}{*}{ SP1394 } & 4.74 & 43.5 & 40.0 & C. carcharias & Hubbell (1996) \\
\hline & 4.82 & 43.9 & & C. carcharias & Randall (1973) \\
\hline F10882 & 4.88 & 39.5 & 34.0 & C. carcharias & Hubbell (1996) \\
\hline
\end{tabular}


Table 1.-(continued)

\begin{tabular}{|c|c|c|c|c|c|}
\hline Specimen ID & Total length $(\mathrm{m})$ & Crown height $(\mathrm{mm})$ UA 2 & Crown width (mm) & Genus & Reference \\
\hline F111882 & 4.88 & 38.0 & 35.0 & C. carcharias & Hubbell (1996) \\
\hline H2888 & 4.88 & 39.5 & 36.0 & C. carcharias & Hubbell (1996) \\
\hline \multirow[t]{2}{*}{ F92982 } & 4.88 & 42.5 & 37.0 & C. carcharias & Hubbell (1996) \\
\hline & 4.88 & 45.0 & & C. carcharias & Randall (1973) \\
\hline \multirow[t]{2}{*}{ LACM 42894} & 4.94 & 34.6 & 33.0 & C. carcharias & Mollet et al. (1996) \\
\hline & 4.96 & 44.2 & 43.1 & C. carcharias & Kenyon (1959) \\
\hline \multirow[t]{3}{*}{ H10886 } & 5.03 & 43.5 & 35.0 & C. carcharias & Hubbell (1996) \\
\hline & 5.10 & 46.0 & & C. carcharias & Follet (1966) \\
\hline & 5.11 & 44.7 & & C. carcharias & Randall (1973) \\
\hline X10892 & 5.16 & 44.5 & 38.0 & C. carcharias & Hubbell (1996) \\
\hline F7687 & 5.18 & 48.5 & 35.0 & C. carcharias & Hubbell (1996) \\
\hline H8993 & 5.18 & 40.5 & 37.0 & C. carcharias & Hubbell (1996) \\
\hline H3884 & 5.18 & 40.0 & 39.0 & C. carcharias & Hubbell (1996) \\
\hline F82817 & 5.18 & 44.5 & 39.0 & C. carcharias & Hubbell (1996) \\
\hline F22490 & 5.18 & 46.0 & 39.0 & C. carcharias & Hubbell (1996) \\
\hline \multirow[t]{2}{*}{ N11693 } & 5.23 & 45.0 & 43.0 & C. carcharias & Hubbell (1996) \\
\hline & 5.30 & 48.3 & & C. carcharias & Mollet et al. (1996) \\
\hline R92185 & 5.36 & 47.5 & 42.0 & C. carcharias & Hubbell (1996) \\
\hline \multirow[t]{2}{*}{ LACM CCS85-9 } & 5.37 & 47.0 & 39.9 & C. carcharias & Mollet et al. (1996) \\
\hline & 5.37 & 49.3 & & C. carcharias & Randall (1973) \\
\hline F52683 & 5.38 & 39.5 & 38.0 & C. carcharias & Hubbell (1996) \\
\hline X11384B & 5.47 & 45.0 & 37.0 & C. carcharias & Hubbell (1996) \\
\hline \multirow[t]{2}{*}{ X11384B } & 5.47 & 45.0 & & C. carcharias & Mollet et al. (1996) \\
\hline & 5.52 & 40.0 & 37.0 & C. carcharias & Mollet et al. (1996) \\
\hline $\mathrm{X} 1138 \mathrm{C}$ & 5.53 & 40.0 & & C. carcharias & Mollet et al. (1996) \\
\hline H10991 & 5.54 & 43.0 & 36.0 & C. carcharias & Hubbell (1996) \\
\hline $\mathrm{X} 11384 \mathrm{~A}$ & 5.54 & 41.0 & 37.0 & C. carcharias & Hubbell (1996) \\
\hline F82380 & 5.54 & 49.0 & 41.0 & C. carcharias & Hubbell (1996) \\
\hline L11685 & 5.63 & 48.0 & 43.0 & C. carcharias & Hubbell (1996) \\
\hline L11985 & 5.63 & 49.0 & & C. carcharias & Mollet et al. (1996) \\
\hline F42787 & 5.64 & 48.0 & 36.0 & C. carcharias & Hubbell (1996) \\
\hline SW31287 & 5.64 & 52.0 & 46.0 & C. carcharias & Hubbell (1996) \\
\hline M91683 & 5.76 & 45.5 & 42.0 & C. carcharias & Hubbell (1996) \\
\hline H5384 & 5.94 & 49.0 & 36.0 & C. carcharias & Hubbell (1996) \\
\hline F7282 & 5.94 & 44.5 & 39.0 & C. carcharias & Hubbell (1996) \\
\hline H112690 & 5.94 & 45.0 & 40.0 & C. carcharias & Hubbell (1996) \\
\hline LJVC-870303 & 6.00 & 48.6 & 50.0 & C. carcharias & Mollet et al. (1996) \\
\hline \multirow[t]{3}{*}{ CV. CGP } & 6.70 & 56.0 & 53.0 & C. carcharias & Adnet et al. (2009) \\
\hline & 7.01 & 46.9 & 38.4 & C. carcharias & Mollet et al. (1996) \\
\hline & 7.01 & 51.6 & & C. carcharias & Cappo (1988) \\
\hline
\end{tabular}

face, a slightly convex to flat labial face, and a large v-shaped neck (Fig. 3). Two root lobes are welldifferentiated and rounded on the basal root edge. The crown height is $92.2 \mathrm{~mm}$ and the crown width is $81.3 \mathrm{~mm}$. The total height of the tooth measured perpendicular from the apex of the tooth to the baseline of the root is $123.96 \mathrm{~mm}$.

The tooth is symmetrical and nearly perpendicular, only slightly slanted $\left(2.1^{\circ}\right)$. For this reason, the mesial crown edge length is $102.0 \mathrm{~mm}$ while the distal 


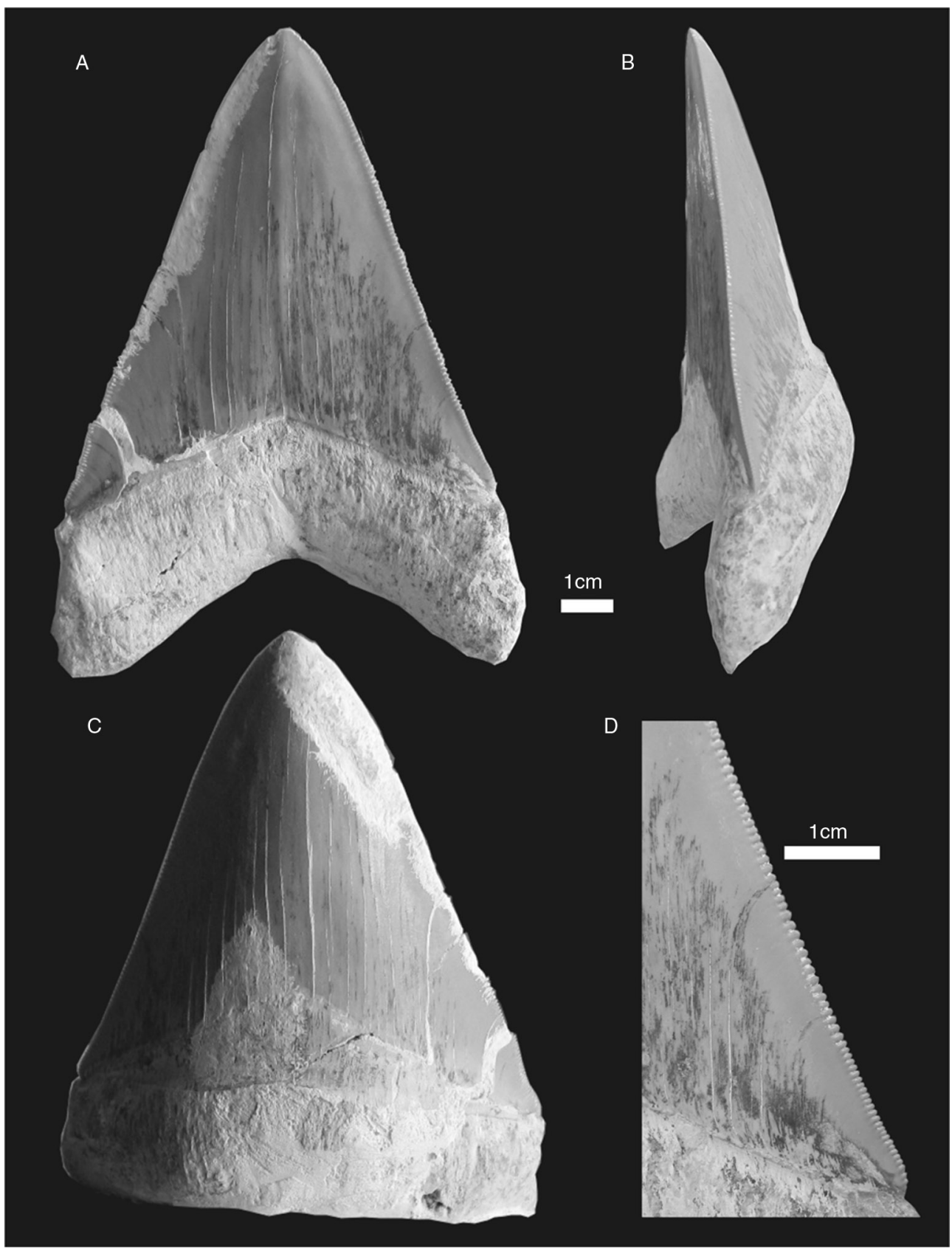

Fig. 3.-Tooth recorded in the Tortonian diatomites from Porcuna (Eastern Guadalquivir Basin). A. Labial view. B. Messial edge view. C. Lingual view. D. Detail of serration in the mesial edge.

crown edge length is $94.8 \mathrm{~mm}$. The size of the teeth varies within the jaw, anterior teeth being large and symmetrical, whereas the large posterior teeth are asymmetrical and feature slanted crowns (Applegate \& Espinosa-Arrubarrena, 1996; Hubbell, 1996; Pimiento et al., 2010). Taking into account the symmetry and the size, this tooth probably corresponds to the upper anterior (A2 or A3 s. Hubbell, 1996; or I or III s. Applegate \& Espinosa-Arrubarrena, 1996) or the second upper lateral position.

The cutting edge presents 135 serrations in the mesial crown edge and 126 serrations in the distal crown edge (Fig. 3D). There are approximately 13 serrations per $\mathrm{cm}$, and they are smaller and denser close 
to the root and the apex. The points of basal serrations are oriented $90^{\circ}$ with respect to the cutting edge.

\section{Discussion}

Due to the fact that the cartilaginous skeleton of chondrichthyans is only preserved in rare instances (e.g. Uyeno et al., 1990; Shimada, 1997; Ehret et al., 2009a; Kriwet et al., 2014), the lack of more complete fossil specimens has led to conflicting interpretations about taxonomy. The taxonomic assignment of this species has long been debated and there are two main interpretations:

A) The megalodon shark is placed in the genus Carcharocles (Family Otodontidae) (Casier, 1960; Gluckman, 1964; Capetta, 1987; Ward \& Bonavia, 2001; Nyberg et al., 2006; Ehret et al., 2009a, 2012; Pimiento et al., 2010).

B) The genus of megalodon shark is congeneric with the living white shark Carcharodon carcharias (Family Lamnidae) (Uyeno et al., 1989, Applegate, 1991; Applegate \& Espinosa-Arrubarrena, 1996; Gottfried et al., 1992, 1996; Purdy, 1996).

We follow the first hypothesis, where C. megalodon is separated from genus Carcharodon on the basis of tooth features such as large size, absence of lateral denticles, and fine serrations - as opposed to a small size, large serrations and the presence of lateral denticles in C. carcharias. However, Carcharocles and Carcharodon are included in the Order Lamniformes, and in the absence of living members of Otodontidae, Carcharodon carcharias is the most analogous species available.

\section{Size estimation}

Among the different measurements on $C$. carcharias, the crown height of the upper anterior tooth A2 presents a higher correlation with the total length of the specimen $(r=0.92)$ than the crown width ( $r=0.53$ ) (Fig. 4). In addition, the correlation is extremely good between the crown width and crown height in the case of $C$. megalodon $(r=0.94)$, better than in $C$. carcharias $(r=0.83$ ) (Fig. 5). For these reasons, commonly, for the estimation of total length of $C$. megalodon from fossil teeth in comparison with the most analogous specie $C$. carcharias, it is used the crown height only.
The largest tooth specimen of C. megalodon is the first upper anterior tooth of the Field Museum of Natural History of Chicago (specimen PF 1168), measuring $168 \mathrm{~mm}$ in total height and $125 \mathrm{~mm}$ in total width, and the 2nd upper lateral tooth of the British Museum of Natural History (specimen P10725), with $154 \mathrm{~mm}$ total height and $134 \mathrm{~mm}$ total width.

Applegate \& Espinosa-Arrubarrena (1996) estimated $12 \mathrm{~m}$ length for the individual having the first upper anterior tooth of the Field Museum (Chicago). This estimation was based on comparison with the same tooth of $C$. carcharias, of known length. C. megalodon dentition is apparently similar in morphology and the number of tooth rows to that of C. carcharias (Uyeno et al., 1989). However, the jaws of $C$. megalodon must be somewhat more robust, larger and thicker, having more massive muscles than those of the C. carcharias (Gottfried et al., 1996). Correspondingly to great jaws and teeth, the head would have most likely been massive as well, with a large branchial region for respiration. In turn, a large stomach and intestine would be necessary for processing large prey, meaning a morphology similar to $C$. carcharias but more robust.

Previous authors assume that the ratio of upper A2 tooth size to total length of the C. megalodon is similar to that in white sharks, and that tooth size increased along with the total length of the shark in both species. The upper A2 tooth in Recent white sharks ranges in size from 56-63 $\mathrm{mm}$ height and 40-50 $\mathrm{mm}$ width for adult females, with a total length of 490-600 cm (Gottfried et al., 1996). A simple method for obtaining a relative total length ratio of the $C$. megalodon specimen from the Guadalquivir Basin with respect to the white shark consists of determining the tooth height ratio of the C. carcharias and C. megalodon from the Guadalquivir Basin. In the case of the C. carcharias, Gottfried et al. (1996) propose an average height for the upper A2 tooth of $59.2 \mathrm{~mm}$, corresponding to an average total length of $550 \mathrm{~cm}$.

\section{$550 \mathrm{~cm} \times 92.2 \mathrm{~mm} / 59.2 \mathrm{~mm}=856.6 \mathrm{~cm}$}

According to this method, the studied tooth belonged to a specimen around $8.5 \mathrm{~m}$ in length.

Using the upper A2 height measurements from 85 specimens of C. carcharias (Table 1; Fig. 4), a linear least-squares regression was calculated following Gottfried et al. (1996). 


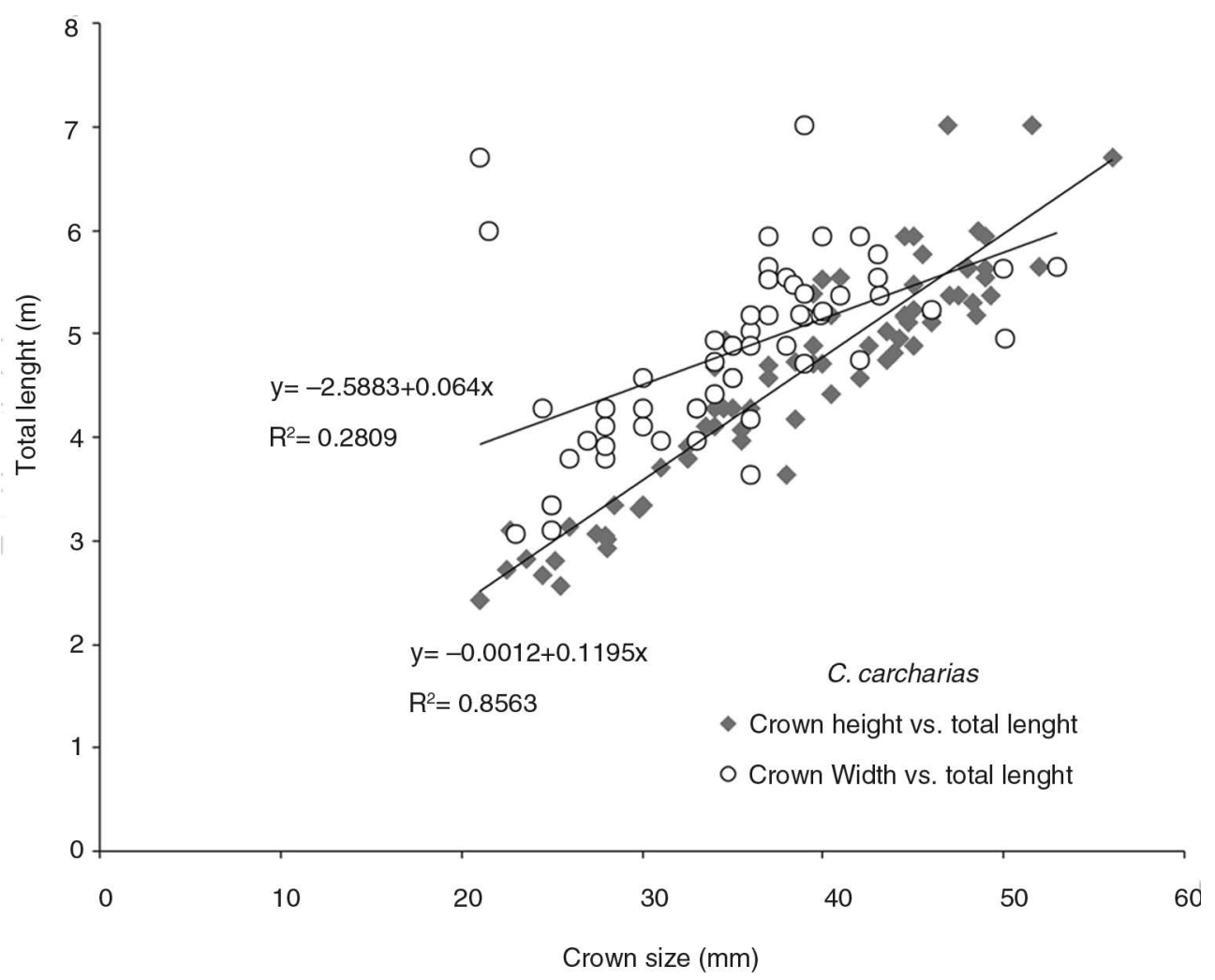

Fig. 4.-Linear relationship between the different crown measurements of the upper second anterior tooth (crown height and crown width) and the total length in Carcharodon carcharias.

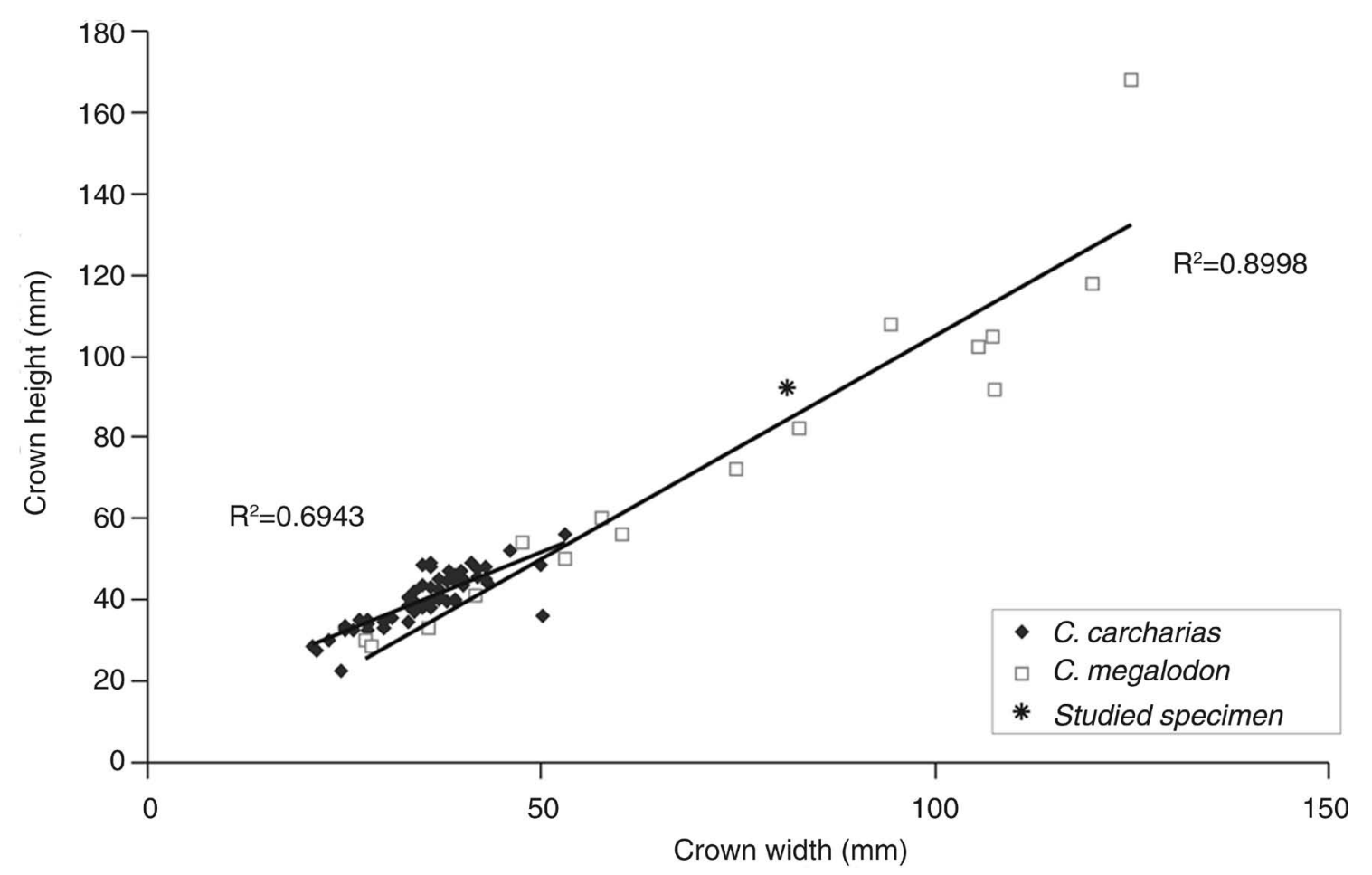

Fig. 5.-Comparison of crown width vs. crown height in C. carcharias and C. megalodon. 


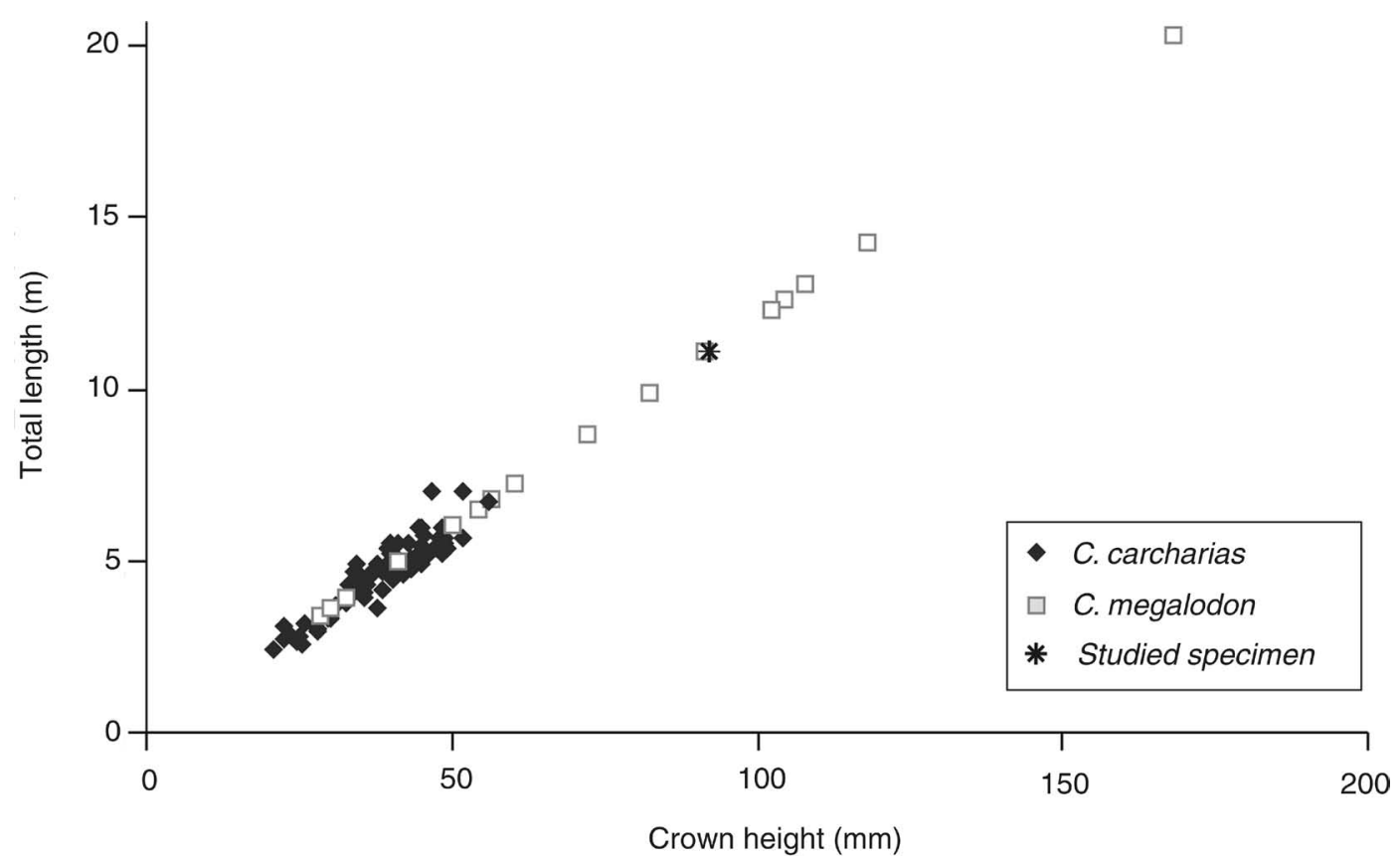

Fig. 6. - Linear relationship between the crown height of the upper second anterior tooth and the total length in Carcharodon carcharias and Carcharocles megalodon. Note total length in C. megalodon calculated according to regression equation of Shimada (2002).

Total Length $(\mathrm{m})=a+b($ upper A2 height $(\mathrm{mm}))$

where $a$ and $b$, as calculated, were -0.001 and 0.119 , respectively ( $r^{2}=0.85$; Fig. 4). Using $92.2 \mathrm{~mm}$ as the crown height for the C. megalodon specimen of Porcuna, we obtain $-0.001+0.119(92.2 \mathrm{~mm})=10.97 \mathrm{~m}$.

Shimada (2002) proposes a linear least-square regression based on relationship between crown height and total length in $C$. carcharias, but taking into account all the positions of the tooth set. This relation is calculated as:

Total Length $(\mathrm{cm})=a+b($ Crown Height $(\mathrm{mm}))$

with $a$ being a constant and $b$ being the slope of regression line. Shimada (2002) propose $a$ and $b$ values for predicting the total length of any tooth from C. carcharias.

Bearing in mind that the tooth from Porcuna $(92.2 \mathrm{~mm})$ is probably an upper anterior tooth A2, $a=-2.160$ and $b=12.103$ (Shimada, 2002):

Total length $=-2.160+12.103(92.2 \mathrm{~mm})=1113 \mathrm{~cm}$

That is, the tooth of Porcuna belonged to an adult, and is in the large size range of specimens of C. megalodon (Fig. 6).
According to Shimada's (2002) method, the largest tooth of C. megalodon, the upper anterior A2 of the Field Museum of Natural History of Chicago (specimen PF 1168), which reaches a crown height of $168 \mathrm{~mm}$, would have belonged to a shark $20.31 \mathrm{~m}$ long (Fig. 6); and the second upper lateral tooth of the British Museum of Natural History (specimen P10725), reaching a crown height of $154 \mathrm{~mm}$, belonged to a shark $20.73 \mathrm{~m}$ long.

\section{Palaeoecology}

Tooth structure and size indicate that $C$. megalodon began primarily as a fish feeder and evolved to feed on marine mammals (Applegate \& Espinosa-Arrubarrena, 1996). The almost worldwide distribution of the $C$. megalodon in the Miocene to Pliocene seas in nearshore deposits at moderately high temperature latitudes indicates environmental requirements close to those favouring living $C$. carcharias. These environments are nutrient rich shelf areas where large marine mammals are relatively abundant. The record of bite marks of $C$. megalodon on fossil cetacean remains indicates that whales and dolphins were regular prey (Demèrè \& Cerutti, 1982; Cigala-Fulgosi, 1990; Purdy, 1996; Ehret et al., 2009b). In the Guadalquivir Basin, and 


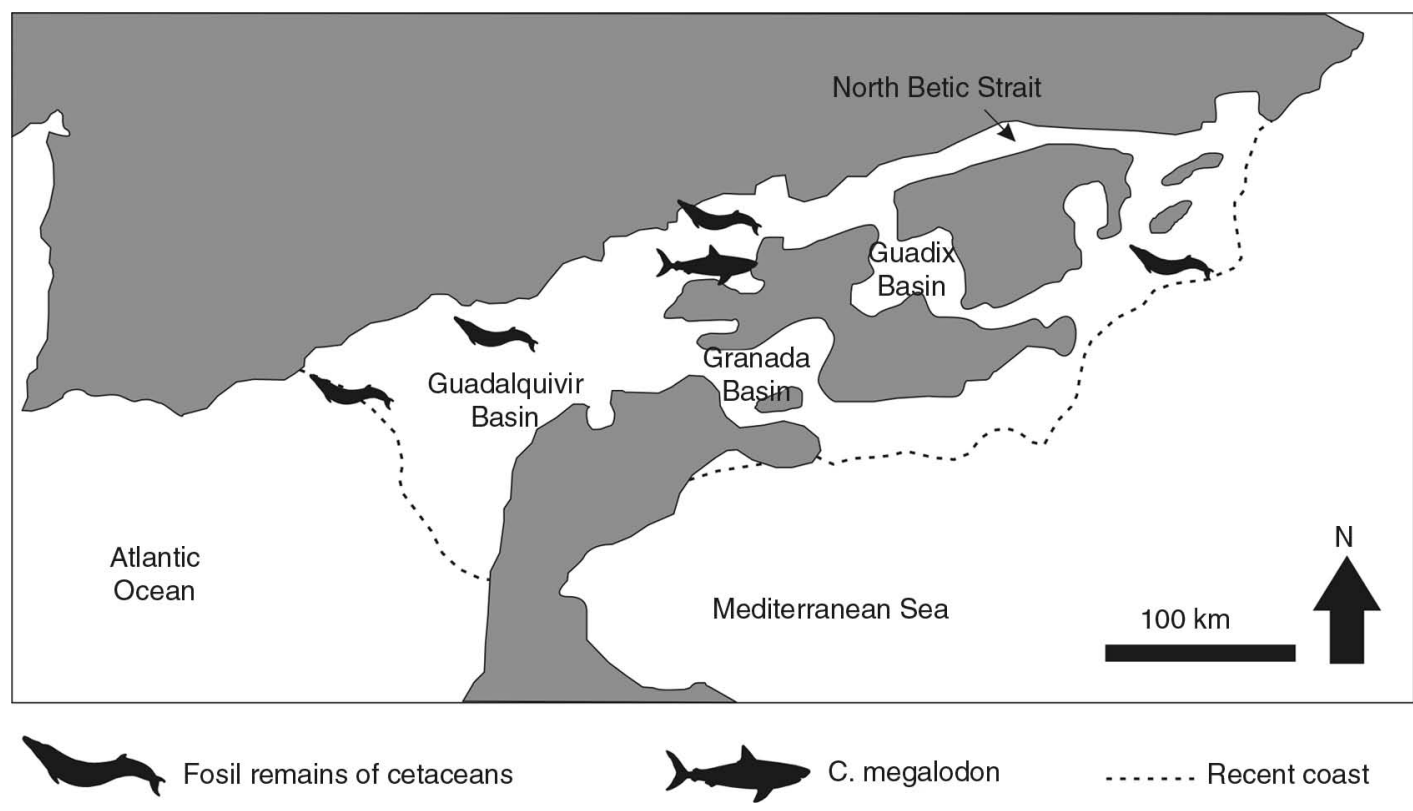

Fig. 7.-Palaeogeography of the Betic-Rifian Cordillera during the Late Tortonian modified from Martín et al. (2014), and location of the fossil remains of cetaceans (Sendra, 1997; Sendra \& Bajo Campos, 2013; Toscano et al., 2013; Reolid et al., 2014) and the C. megalodon teeth studied.

concretely in the sector between Porcuna and Bailén, numerous remains from large marine vertebrates have been recorded, including Isurus, indeterminate pinnipeds and whales (Reolid et al., 2014), which could be potential prey of $C$. megalodon. The palaeogeography of this basin, as an Atlantic branch connecting with the Mediterranean Sea, probably favoured the hunting techniques of $C$. megalodon. Obviously, this is very speculative due the scarce record of marine vertebrate fossils from Upper Miocene in this basin (Fig. 7). However, the record of $C$. megalodon is congruent in a context as the North Betic Strait where high productivity is reported (Molina et al., 1987; Bustillo \& López-García, 1997) favorable for marine mammals, also recorded in the same basin (Reolid et al., 2014).

\section{Conclusions}

A large shark tooth is recorded in Tortonian diatomites of the Eastern Guadalquivir Basin (Porcuna, Jaén). The large size ( $92.2 \mathrm{~mm}$ crown height), triangular shape, broad serrated crown, lingual face convex, labial face flat, large neck, and robust, thick angled root determine that this specimen corresponds to Carcharocles megalodon. The symmetry with a low slant indicates this is an upper anterior tooth. The total length estimated from the tooth crown height is around $11 \mathrm{~m}$.

In the North Betic Strait, which connected the Atlantic Ocean to the palaeo-Mediterranean sea, the interaction of the cold nutrient-rich Atlantic waters with the palaeogeography and the bottom topography caused upwelling, and a high productivity of biogenic silica (diatomites). High nutrients and productivity favoured the presence of large vertebrates such as mysticetid whales, pinnipeds and small sharks (Isurus) recorded in the Upper Miocene deposits of this area. These large vertebrates constitute potential prey of C. megalodon. The palaeogeography of this basin, as an Atlantic branch connecting with the Mediterranean Sea, was probably well suited to the hunting techniques of $C$. megalodon.

\section{ACKNOWLEDGEMENTS}

The research activity of M. Reolid was supported by Projects RYC-2009-04316 (Ramón y Cajal Program) and P11-RNM-7408 (Junta de Andalucía). The research of J.M. Molina was sustained by RNM-200 Research Group. The authors are indebted to Luis Emilio Vallejo Delgado (Curator of Museo Obulco, Porcuna) for helping during the work in the museum. Catalina Pimiento (University of Florida and Smithsonian Tropical Research Institute) helped with the literature and first stages of classifying 
shark teeth from the Eastern Guadalquivir Basin. The authors are indebted to the reviewers Carlos Martínez (University of Bristol) and an anonymous reviewer for their valuable comments. We thank Jean Sanders for reviewing the grammar.

\section{References}

Adnet, S.; Balbino, A.C.; Antunes, M.T. \& Marín-Ferrer, J.M. (2010). New fossil teeth of the white shark (Carcharodon carcharias) from the Early Pliocene of Spain. Implications for its paleoecology in the Mediterranean. Neues Jarbush Geologische Paläontologische Abhandlungen, 256: 7-16. http://dx.doi. org/10.1127/0077-7749/2009/0029

Applegate, S.P. (1991). A status report on the genus Carcharodon, the great white shark, and its fossil record. Journal of Vertebrate Paleontology, 11 (supp. 3): 14A-15A. http://dx.doi.org/10.1080/02724634.1991. 10011425

Applegate, S.P. \& Espinosa-Arrubarrena, L. (1996). The fossil history of Carcharodon and its possible ancestor, Cretolamna: a study in tooth identification. In: Great White Sharks: the biology of Carcharodon carcharias (Klimley, A.P. \& Ainley, D.G., Eds.), Academic Press, San Diego, 19-36.

Areitio, A. (1877). Peces fósiles de Lorca. Anales de la Sociedad Española de Historia Natural, 6: 50-51.

Balbino, A.C. (1995). Seláceos (pisces) do Miocénico terminal da Bacia de Alvalade (Portugal). Sistemática, ecología, paleoambientes, comparação com faunas actuáis. PhD Thesis Universidade de Evora, 188 pp.

Bendix-Almgreen, S.E. (1983). Carcharondon megalodon from the Upper Miocene of Denmark, with comments on elasmobranch tooth enameloid: coroïn. Bulletin of Geological Society of Denmark, 32: 1-32.

Bigelow, H.B. \& Schroeder, W.C. (1948). Fishes of the Western North Atlantic, Part 1. Yale University, New Haven, 576 pp.

Bustillo, M.A. \& López-García, M.J. (1997). Age, distribution and composition of Miocene diatom bearing sediments in the Guadalquivir Basin, Spain. Geobios 30: 335-350. http://dx.doi.org/10.1016/S0016-6995 (97)80193-3

Casier, E. (1960). Note sur la collection des poisons paleochnes et iochnes de l'Enclave de Congo. Annales Museum Royal Congo Belge, 30: 1-28.

Capetta, H. (1987). Chondrichthyes. II. Mesozoic and Cenozoic Elasmobranchii. Handbook of Paleoichthyology Vol. 3B. Stuttgart \& New York: Gustav Fischer Verlag, 193 pp.

Cappo, M. (1988). Size and age of the white pointer shark Carcharodon carcharias (Linnaeus): was Peter Riseley's white pointer a world record? Safish, 13: 11-13.

Cigala-Fulgosi, F. (1990). Predation (or possible scavenging) by a great white shark on an extinct species of bottlenosed dolphin in the Italian Pliocene. Tertiary Research, 12: 17-36.
Cione, A.L.; Cabrera, D.A. \& Barla, M.J. (2012). Oldest record of the Great White Shark (Lamnidae, Carcharodon; Miocene) in the Southern Atlantic. Geobios, 45: 167-172. http://dx.doi.org/10.1016/j. geobios.2011.06.002

Cione, A.L.; Cabrera, D.A.; Azpelicueta, M.M.; Casciotta, J.R. \& Barla, M.J. (2013). Peces del Mioceno marino y continental en Entre Ríos, Oriente Central de Argentina. In: El Neógeno de la Mesopotamia argentina (Brandoni, D. \& Noriega, J.I., Eds.), Asociación Paleontológica Argentina, Publicación Especial 14: 71-83.

Compagno, L.J.V. (1984). FAO species catalogue. Vol. 4., Sharks of the world. An annotated and illustrated catalogue of shark species known to date. Part 1, Hexanchiformes to Lamniformes. FAO Fisheries Synopsis, 125: 1-249.

Demèrè, T.A. \& Cerutti, R.A. (1982). A Pliocene shark attack on a cetotheriid whale. Journal of Paleontology, 56: 1480-1482.

Ehret, D.J.; Hubbell, G. \& MacFadden, B.J. (2009a). Exceptional preservation of the white shark Carcharodon (Lamniformes, Lamnidae) from the early Pliocene of Peru. Journal of Vertebrate Paleontology, 29: 1-13. http://dx.doi.org/10.1671/039.029.0113

Ehret, D.J.; MacFadden, B.J. \& Salas-Gismondi, R. (2009b). Caught in the act: trophic interactions between a 4-million-year-old white shark (Carcharodon) and mysticete whale from Peru. Palaios 24: 329-333. http://dx.doi.org/10.2110/palo.2008.p08-077r

Ehret, D.J.; MacFadden, B.J.; Jones, D.S.; Devries, T.J.; Foster, D.A. \& Salas-Gismondi, R. (2012). Origin of the white shark Carcharodon (Lamniformes: Lamnidae) based on recalibration of the Upper Neogene Pisco Formation of Peru. Palaeontology, 55: 1139-1153. http:// dx.doi.org/10.1111/j.1475-4983.2012.01201.x

García, E.X.M.; Telles-Antunes, M.; Cáceres-Balbino, A.; Ruiz-Muñoz, F. \& Civis-Llovera, J. (2009). Los tiburones Lamniformes (Chondrichthyes, Galeomorphii) del Plioceno inferior de la Formación Arenas de Huelva, suroeste de la Cuenca del Guadalquivir, España. Revista Mexicana de Ciencias Geológicas, 26: 674-686.

García-García, F.; Corbí, H.; García-Ramos, D.A.; Soria, J.M.; Tent-Manclús, J.E. \& Viseras, C. (2014). El sector nororiental de la cuenca de antepais del Guadalquivir (Cordillera Bética, Mioceno Superior): Estratigrafía, cronología y evolución sedimentaria. Revista de la Sociedad Geológica de España 27: 187-204.

Glickman, L.S. (1964). Class Chondrichthyes Subclass Elasmobranchii. In: Fundamentals of Paleontology, vol. 11 (Obruchev, D.V., Ed.). Nauka SSSR, MoscowLeningrad: 196-237.

Gottfried, M.D.; Compagno, L.J.V. \& Bowman, S.C. (1992). Skeletal anatomy of Carcharodon megalodon: Inferences based on comparisons with the Recent species Carcharodon carcharias. Journal of Vertebrate 
Paleontology, 12 (Supp.3): 30A. http://dx.doi.org/ 10.1080/02724634.1992.10011483

Gottfried, M.D.; Compagno, L.J.V. \& Bowman, S.C. (1996). Size and skeletal anatomy of the Giant "Megatooth" Shark Carcharodon megalodon. In: Great White Sharks: the biology of Carcharodon carcharias (Klimley, A.P. \& Ainley, D.G., Eds.), Academic Press, San Diego, 55-66.

Hubbell, G. (1996). Using tooth structure to determine the evolutionary history of the white shark. In: Great White Sharks: the biology of Carcharodon carcharias (Klimley, A.P. \& Ainley, D.G., Eds.), Academic Press, San Diego, 9-18.

Kenyon, K.W. (1959). A 15-foot maneater from San Miguel Island, California. California Fish Game, 45: 58-59.

Kriwet, J.; Mewis, H. \& Hampen, O. (2014). A partial skeleton of a new lamniform mackerel shark from the Miocene of Europe. Acta Paleontologica Polonica, in press. http://dx.doi.org/10.4202/app.00066.2014

Leriche, M. (1926). Les poissons Néogènes de la Belgique. Mémoires Musée Royal d'Histoire Naturelle de Belgique, 32: 368-472.

López-García, M.J. \& Bustillo, M.A. (1994). Los sedimentos con diatomeas del Mioceno en la cuenca del Guadalquivir: edad y composición litológica. Estudios Geológicos, 50: 71-90.

Martín, J.M.; Puga-Bernabéu, A.; Aguirre, J. \& Braga, J.C. (2014). Miocene Atlantic-Mediterranean seaways in the Betic Cordillera (Southern Spain). Revista de la Sociedad Geológica de España, 27: 175-186.

Meseguer Pardo, J. (1924). Estudio de los yacimientos de azufre de las provincias de Murcia y Albacete. Boletín del Instituto Geológico y Minero de España, 5: 3-83.

Molina, J.M.; Bustillo, M.A. \& Ruiz-Ortiz, P.A. (1987). The marine diatomite-dominated sediments of the Guadalquivir Basin in the Jaen province (Upper Miocene. Southern Spain). 8th IAS Regional Meeting of Sedimentolology, Tunis, 353-354.

Mollet, E.F.; Cailliet, G.M.; Klimley, A.P.; Ebert, D.A.; Testi, A.D. \& Compagno, L.J.V. (1996). A review of length validation methods and protocols to measure large white sharks. In: Great White Sharks: the biology of Carcharodon carcharias (Klimley, A.P. \& Ainley, D.G., Eds.), Academic Press, San Diego, 91-108.

Nyberg, K.G.; Ciampaglio, C.N. \& Wray, G.A. (2006). Tracing the ancestry of the Great White Shark, Carcharondon carcharias, using morphometric analyses of fossil teeth. Journal of Vertebrate Paleontology, 26: 806-814. http://dx.doi.org/10.1671/0272-4634(2006) 26[806:TTAOTG]2.0.CO;2

Pimiento, C.; Ehret, D.J.; MacFadden, B.J. \& Hubbell, G. (2010). Ancient nursery area for the extinct giant shark Megalodon from the Miocene of Panama. Plos One, 5: e10552. http://dx.doi.org/10.1371/journal. pone. 0010552

Purdy, R.W. (1996). Paleoecology of fossil white sharks. In: Great White Sharks: the biology of Carcharodon carcharias (Klimley, A.P. \& Ainley, D.G., Eds.), Academic Press, San Diego, 67-78.

Randall, J.E. (1973). Size of the Great White shark (Carcharodon). Science 180(4095): 169-170. http://dx.doi. org/10.1126/science.181.4095.169

Reolid, M.; García-García, F.; Tomašových, A. \& Soria, J.E. (2012). Thick brachiopod Shell concentrations from prodelta and siliciclastic ramp in a Tortonian Atlantic-Mediterranean strait (Miocene, Guadix Basin, southern Spain). Facies, 58: 549-571. http:// dx.doi.org/10.1007/s10347-012-0296-2

Reolid, M.; García-García, F.; Martín-Suárez, E. \& Reolid, J. (2014). Fossil assemblages of delta bottomset facies of the Upper Miocene of Eastern Guadalquivir Basin. ¡Fundamental! 24: 199-201.

Riaza, C. \& Martínez del Olmo, W. (1996). Depositional model of the Guadalquivir-Gulf of Cadiz Tertiary basin. In: Tertiary basins of Spain: the stratigraphic record of crustal kinematics (Friend, P.F. \& Dabrio, C.J., Eds.), Cambridge University Press, Cambridge, 330-338.

Royce, W.F. (1963). First record of white shark Carcharondon carcharias from southeastern Alaska. Copeia, 1: 179.

Sendra, J. (1997). Los yacimientos de mamíferos marinos del Neógeno del Sur de la provincia de Alicante. In: XIII Jornadas de Paleontología (Grandal, A.; Gutiérrez-Marco, J.C. \& Santos, L., Eds.), Sociedad Española de Paleontología, 237-240.

Sendra, J. \& Bajo Campos, I. (2013). Evidencias tafonómicas de carroñeo o predación sobre cetáceos: el neurocráneo del Tortoniense de Burguillos (Sevilla). In: XXIX Jornadas de Paleontología (ÁlvarezVázquez, C. \& López Rodríguez, I., Eds.), Sociedad Española de Paleontología, 125-126.

Shimada, K. (1997). Skeletal anatomy of the Late Cretaceous lamniform shark, Cretoxyrhina mantelli, from the Niobrara Chalk in Kansas. Journal of Vertebrate Paleontology, 17: 642-652. http://dx.doi.org/10.108 0/02724634.1997.10011014

Shimada, K. (2002). The relationship between the tooth size and total body length in the white shark, Carcharodon carcharias (Lamniformes: Lamnidae). Journal of Fossil Research, 35: 28-33.

Siccardi, E.; Gosztomy, A.E. \& Menni, R.C. (1981). La presencia de Carcharodon carcharias e Isurus oxyrinchus en el mar Argentino. Chondrichthyes, Lamniformes. Physis, A, 39: 55-62.

Tjalsma, R.C. (1971). Stratigraphy and foraminifera of the Neogene of the Eastern Guadalquivir Basin (Southern Spain). Utrecht Micropaleontological Bulletins, 4: 1-161.

Toscano, A.; Abad, M.; Ruiz, F.; Muñiz, F.; Álvarez, G.; García, E.X. \& Caro, J.A. (2013). Nuevos restos de Scaldicetus (Cetacea, Odontoceti; Physeteridae) del Mioceno superior, sector occidental de la Cuenca del Guadalquivir (sur de España). Revista Mexicana de Ciencias Geológicas, 30: 436-445. 
Uyeno, T.; Sakamoto, O. \& Sekine, H. (1989). The description of an almost complete tooth set of Carcharodon megalodon from a Middle Miocene bed in Saitama Prefecture, Japan. Bulletin of Saitama Museum of Natural History, 7: 73-85.

Uyeno, T.; Kondo, Y. \& Inoue, K. (1990). A nearly complete tooth set and several vertebrae of the lamnid shark Isurus hastalis from the Pliocene of Chiba, Japan. Journal of the Natural History Museum and Institute, Chiba, 3: 15-20.

Ward, D.J. \& Bonavia, C.G. (2001). Additions to, and a review of, the Miocene shark and ray fauna of Malta. The Central Mediterranean Naturalist, 3: 131-146. 